Agnieszka Kwiatkowska

Instytut Filologii Polskiej, Uniwersytet im. Adama Mickiewicza w Poznaniu

\title{
Jak badać literaturę dokumentu osobistego, czyli bliskie spotkania z Bronisławą Waligórską
}

Nakładem Wydawnictwa Instytutu Badań Literackich w Warszawie ukazała się właśnie książka Bronisławy Waligórskiej Listy $z$ cytadeli 1886 w opracowaniu Moniki Rudaś-Grodzkiej. Tom otwiera serię Archiwum Kobiet, w której - jak zapewniono we wstępie - prezentowane będą „nowatorskie pod względem edytorskim i badawczym opracowania niepublikowanych dotychczas tekstów z zakresu literatury dokumentu osobistego" [Waligórska 2018: 9] przygotowywane przez Zespół Archiwum Kobiet IBL PAN.

Autorka XIX-wiecznych listów, Bronisława Waligórska - działaczka socjalistyczna - została aresztowana i osadzona w Cytadeli Warszawskiej w lipcu 1886 roku. Była oskarżona o wspieranie działań Proletariatu, tłumaczenie i powielanie lewicowych broszur, udział w zorganizowanym zamachu na Piotra Pińskiego oraz planowanie ataku terrorystycznego na Józefa Hurkę. Eskalacja walki ze szpiegami, donosicielami i prowokatorami, która miała miejsce w końcowej fazie działalności Proletariatu, wywołała falę aresztowań, co ostatecznie doprowadziło do rozbicia grupy. $\mathrm{Z}$ więzienia Waligórska pisała listy do siostry Jadwigi, która ją odwiedzała i starała się zaspokoić najpilniejsze potrzeby więźniarki. Zacho- 
wana korespondencja jest świadectwem warunków egzystencji więźniów Cytadeli oraz życia wewnętrznego Bronisławy, która stopniowo upadała na duchu i traciła wolę walki o przetrwanie. 31 grudnia 1886 roku połknęła siarkę z zapałek; zmarła wskutek zatrucia 3 stycznia 1887 roku.

Edycji listów pisanych z więzienia towarzyszą rozmaite dodatki: nota edytorska, omówienie zasad wydania, kalendarium, biografia więzienna głównej bohaterki oraz wybór dokumentów dotyczących śledztwa. Najważniejszą częścią tomu pozostaje jednak korespondencja, jaką Waligórska kierowała do swej siostry. Pisała najpierw na brudno, rysikiem na tabliczce lub na starannie zgromadzonych skrawkach papieru, potem przepisywała tekst na czyste arkusze, które bardzo oszczędzała. Donosiła siostrze: „[...] robię mikroskopijne litery na tablicy żeby się jaknajwięcej zmieściło - resztę napiszę na przeróżnych świstkach które starannie zbieram po cukrze, mydle itd." [Waligórska 2018: 97]'. W celi nie można było używać pióra, brakowało też dobrego atramentu. Bronisława pisała zaostrzoną zapałką i w listach przekomarzała się z siostrą:

Wiesz co Jadwiga, ty byś nigdy nie miała cierpliwości pisać jak ja! Co litera, maczaj nędzną zapałkę w nędzniejszy jeszcze atrament - ale mam nadzieję, że jak sprawowanie moje dojdzie do $5+$, to dostanę pióro i atrament na bruliony do Ciebie i tłumaczenia. [Waligórska 2018: 102]

Waligórska poprzez żartobliwy ton listów starała się zatuszować pogarszający się z każdym dniem nastrój. Kiedy wspominała o tęsknocie za siostrą, opisywała dojmującą samotność, rozpaczliwie wyznawała: „dla mnie wszystko się już skończyło”, deklarowała zaraz: „[n]iech raz Ci powiem, co mam w sercu, później drwinki wezmą górę jak zwykle" [Waligórska 2018: 102]. W innym liście tak komentowała swoją postawę: „Wiesz co Jadwiga, posiadam jeden, prawdziwy, nieoszacowany przymiot, mianowicie że: albo

1 We wszystkich cytatach z listów Bronisławy Waligórskiej zachowano oryginalną ortografię i interpunkcję. 
zapatruję się na rzeczy od strony komicznej, albo poetyzuję to, co w śmieszność obróconem być nie może” [Waligórska 2018: 120].

Początkowo była pełna optymizmu, próbowała odnaleźć się w więziennej rzeczywistości, jakoś sobie zorganizować życie i pracę. Przykazała siostrze, aby ta zajęła się jej sprawami finansowymi; zalecała sprzedaż srebrnego zegarka i poduszki, spłacenie zobowiązań oraz zakup i przesłanie do więzienia niezbędnych produktów: „trochę herbaty i cukru, mydła szuwaksu” [Waligórska 2018: 91]. Prosiła też o książki: słowniki, gramatykę niemiecką i angielską, podręczniki z rozmówkami, powieść Charlotty Brontë i książkę Talizman flamandzkiego powieściopisarza Hendrika Conscience’a. Opisy bibliograficzne podawała skrótowo, zaledwie sygnalizując tytuły pożądanych pozycji; widocznie Jadwidze dobrze znany był jej księgozbiór i czytelnicze zainteresowania. Wśród przedmiotów pierwszej potrzeby, dzięki którym Bronisława pragnęła stworzyć sobie w celi namiastkę zwyczajnego życia, pojawily się też rzeczy związane z tajemniczym, bliskim obu siostrom, Lutkiem. Waligórska pisała: „Co do Lutka rzeczy chcę tylko gabinetową fotogra[fię] i małą kopertę tekturową z trzema fotografi[ami] i włosami Jego" [Waligórska 2018: 92]. W innym liście dziękowała Jadwidze:

Jest jedna rzecz za którą Ci nie podziękowałam dotąd, choć mam ją już trzy miesiące - To fotografia Lutka - która jest twoją, ale przywiezłaś mi, wiedząc jak ja ją lubię - dziękuję Ci serdecznie za nią. [Waligórska 2018: 104]

Tajemniczy Lutek - postać ważna dla obu sióstr Waligórskich - to być może starszy brat Jadwigi i Bronisławy, Władysław Aleksander Ludwig, który zginął w powstaniu styczniowym w wieku niespełna siedemnastu lat ${ }^{2}$. Można mieć wątpliwości, czy zdrobnienie Lutek pochodzi od imienia „Władysław”, ale istnieje prawdopodobieństwo, że w rodzinie zwracano się do młodego

2 Po przeszukaniu mieszkania Waligórskiej przy ul. Złotej zarekwirowano m.in nekrolog Ludka Garsznita. Nie udało się ustalić dokładnych danych tej osoby, którą mógł być też opisywany w korespondencji sióstr Lutek. 
Waligórskiego drugim lub trzecim imieniem, podobnie jak Paulinę Julię Fryderykę Jadwigę powszechnie nazywano Jadzią. W jednym z ostatnich listów, pisanym, kiedy kondycja psychiczna Bronisławy zdecydowanie się pogorszyła, znajdujemy wzmiankę dotyczącą prawdopodobnie powstania styczniowego. Więźniarka pisze do siostry:

Poczciwa moja Jadwigo, zgadłaś dziś moje gorące pragnienie - wielką mi przyjemność zrobisz, jak mi przyniesiesz Lutka listy do Ciebie. Zbliża się czas najmilszych i najboleśniejszych wspomnień; bo zarazem widzę go jak z rozpromienioną twarzą przygląda się upragnionej choince, a w kilka dni później, leży przy niej, ale już jej nie widzi. [Waligórska 2018: 119]

Czy to myśl o mobilizacji odciągnęła uwagę chłopca od świątecznych dekoracji ?3 Bronisława, rozmyślając o zmarlym Lutku, sama z wolna żegnała się ze światem. W kolejnych listach wspominała przeszłość, dokonywała swoistego rozrachunku z życiem, dziękowała siostrze i przyjaciołom za wsparcie, nie zapomniała nawet o „poczciwej Antosi” - bardzo „przywiązanej Lutka niańce, która raczej najlepszą siostrą dla niego była a nie sługą" [Waligórska 2018: 118].

Autorka Listów z cytadeli 1886 była intelektualistką. Jej korespondencja nie jest tylko świadectwem czasu spędzonego w więzieniu. W listach do siostry poruszała sprawy przyziemne, bytowe, organizacyjne; dzieliła się też refleksjami na temat kultury, literatury i sztuki. Ukończyła wszak dwuletni kurs pedagogiczny i na początku lat 80. XIX wieku pracowała w Warszawie jako prywatna nauczycielka. Była krytyczna wobec powieści Kraszewskiego [Waligórska 2018: 96], lubiła działa francuskich naturalistów, wspominała Georges’a Ohnera, Octave’a Feuilleta, Emila Zolę [Waligórska 2018: 105], tęskniła za książkami pełnymi namiętności i dowcipu. na początku maja. Mało prawdopodobne, aby po śmierci przetransportowano Władysława do rodzinnego domu. Jeśli więc wzmianka o Lutku, który leży koło świątecznego drzewka, ale już go nie widzi, byłaby peryfrazą śmierci, to z pewnością nie może chodzić o Władysława Waligórskiego. 
Waligórska doświadczyła w więzieniu przedmiotowego traktowania - boleśnie odczuwała to, że nie zauważają jej żandarmi i pracownicy więzienia, z którymi nie mogła nawiązać żadnej rozmowy. „Ja tu nie osobą jestem, tylko rzeczą" - pisała [Waligórska 2018: 95]. Najbardziej bała się bezczynności. Pragnęła wypełnić dni więzienne pracą przekładową. Ponieważ paczki były przyjmowane i przekazywane więźniom tylko w soboty, przynagla siostrę: „[...] moja droga spiesz się, proszę Cię, żebym 10 dni jeszcze tak bezczynną nie siedziała!" [Waligórska 2018: 92]. Dbała też bardzo o swoją kondycję fizyczną i psychiczną, co wieczór gimnastykowała się, aby zachować sprawność. W jednym z listów, dziękując za piłkę, pisała:

Czytanie odkładam na wieczór, a w szarą godzinę, rozpoczną się teraz na dobre ćwiczenia gimnastyczne - dzięki Romki piłce; jak się dobrze zmęczę, to będę pewno lepiej spała podziękuj R odemnie i pocałuj ją serdecznie. [Waligórska 2018: 99]

W innym liście nadmieniała:

Prowadzę tryb życia bardzo higieniczny; wstaję rano - idę wcześnie spać po skromnej kolacyi; herbaty wieczorem nie piję, bo mnie zanadto denerwuje - od czasu jak mniej herbaty piję a więcej kawy, to jestem zupełnie zdrowa - pracuję i nie robię sobie mauvais sang [złej krwi] przykremi myślami. [Waligórska 2018: 117]

Waligórska wielokrotnie wspominała o kontroli cenzurowanej korespondencji. Starała się przystosować do obowiązujących zasad, unikała dwuznacznych i metaforycznych sformułowań, o to samo prosiła też siostrę. Obawiała się, że listy, w których będzie zbyt wiele kontrowersyjnych treści, zostaną nie tylko ocenzurowane, ale także zatrzymane przez cenzorów. Kontakt z siostrą był dla niej zbyt cenny, aby miała ryzykować jakiekolwiek zaburzenia w korespondencji. Starała się też - o czym dość ogólnikowo wspomina - uniknąć przykrości, jakie czekałyby ją w przypadku niesubordynacji. W jednym z listów ustalała z Jadwigą kwestie 
dotyczące prania; narzekała na brudne prześcieradła, prosiła o czysty i wykrochmalony szlafrok, a w zakończeniu dodała:

Ponieważ list ten nie zawiera żadnych allegoryi, ponieważ niema w nim mowy ani o jaskółkach, ani o Wenecji, tylko o zwyczajnych brudach, mam nadzieję, ze nie będzie potrzebował trzydziestu kontroli! [Waligórska 2018: 95]

Jak cenzorzy mogliby zinterpretować wzmianki o Wenecji i jaskółkach - nie wiadomo, ale pranie rzeczywiście nie wzbudziło ich niepokoju - list dotarł do adresatki bez żadnych skreśleń. Tymczasem problem z praniem, brak czystej bielizny, środków czystości, szerzący się wszędzie brud był wielką bolączką życia więziennego. W jednym z listów Waligórska [2018: 100] wspominała: „Dodaj do tego, że niektórzy mają swoje inexprimables w tak opłakanym stanie, że brak kawałków w najpotrzebniejszych miejscach”. Gdy Jadwiga nieroztropnie zapytała siostrę, czy lubi swoją celę, ta w odpowiedzi przesłała emocjonalny opis zaplutych ścian, które próbowała oskrobać z zaschniętych brudów kawałkami rozbitej szklanki [Waligórska 2018: 128].

Bronisława rzadko się żaliła. Nie wynikało to tylko z obawy przed cenzurą, ale było też konsekwencją przyjętej wobec zaistniałej sytuacji postawy dzielności. Waligórska czuła się dziedziczką polskiej tradycji narodowowyzwoleńczej, pochodziła z powstańczej rodziny, wychowała się w duchu admiracji dla ofiar składanych na ołtarzu ojczyzny, które należy ponosić z godnością i bez słowa skargi. W więzieniu nie dojadała; z drobnych wzmianek, próśb o przesłanie imbryka do herbaty, bo „chleb maczany w gorącem, jest sytniejszy”, a „kolacyje i tak nie sute” [Waligórska 2018: 99], wyłania się obraz fatalnych warunków, w jakich musiała przebywać, przywodzący na myśl opisy więzienia z Mickiewiczowskich Dziadów. Waligórska daleka była jednak od budowania martyrologii. Gdy na kolację zamiast chleba i zimnej herbaty zaczęła dostawać zupę, lakonicznie zapisała w notatniku „plus faim” (już niegłodna) i natychmiast doniosła siostrze: „[...] byłoby łakomstwo z mojej strony, a marnotrawstwo z Twojej, gdybyś mi coś do jedzenia przynosiła”, po czym dodała tylko: „[... ] ale kawy mi 
bardzo brak" [Waligórska 2018: 101]. O niedostatku jedzenia i marnej jakości potraw wspominała raczej żartobliwie, np. trawestując wiersz Goethego, pytała:

Znasz Ty ten kraj gdzie bobkowe liście rosną? Nie? no to Ci powiem: rosną one najobficiej w cytadeli War[szawskiej] u stóp 1ogo Pawilonu. Prawdopodobnie, uprawia je jakiś amator, tak jak w Holandyi uprawiają namiętni amatorzy tulipany. Ale tan nasz, nie zazdrośny przynajmniej, i pozwala rwać ile się komu podoba. Ztąd zapewne ta obfitość pływająca co dzień w każdej zupie - wczoraj np. w niewielkiej porcyi kaszy hreczanej, podanej na kolacyę, znalazłam tylko 6 listków. [Waligórska 2018: 114]

Jak bardzo musiała być głodna, można wnioskować z niemałej liczby wzmianek o jedzeniu, które Bronisława wspomina z czułością i rozrzewnieniem, jako część dawno minionej, przyjaznej rzeczywistości. Często chyba rozmyśla nie tylko o chwilach spędzanych z rodziną i przyjaciółmi, lecz także o wspólnych posiłkach, za którymi bardzo tęskniła. Przywołując z pamięci utarczki z siostrą, szczegółowo opisała pojednawcze uczty, które zdecydowanie poprawiały humory obu dziewczętom:

Serca nasze obfitsze w uczucia, niż kieszenie w grosze - więc pańskich przysmaczków ani delikatesów tam nie było. Zjadło się pajdę świeżego chleba - do tego porządny kawał kiełbasy z czosnkiem, lub kiszki pasztetowej, lub sera śmierdzącego czasami to wszystko razem - wypiło się kilka szklanek herbaty hojnie pomieszanej z arakiem, przy którym ulotniła się ostatnia kropelka żółci. [Waligórska 2018: 132]

Waligórska miała wyrzuty sumienia, że za bardzo angażuje siostrę swoją osobą. Jadwiga - aby skutecznie wspierać uwięzioną przeniosła się do Warszawy, gdzie usilnie zabiegała o pozyskanie środków na własne potrzeby i paczki posyłane do więzienia. Bronisława czuła, że staje się coraz większym ciężarem dla bliskich. W grudniu 1886 roku pisała do Jadwigi: 
Już od dawna uważam z Twych listów że Ci jest zupełnie źle w Warszawie - bo nawet jak przybierasz ton wesoły, to się w nim zawsze żółć przebija [...]. [...] jak jesteś słaba, to na dorożkę nie masz - a na zbytki dla mnie urządzasz loteryję, przyznaj że nie egoistką, ale czymś gorszym trzeba być żeby na to patrzyć obojętnym okiem. [Waligórska 2018: 125]

Relacja z siostrą niosła Bronisławie pociechę, ale była też dla niej swoistym zobowiązaniem. Z biegiem czasu Waligórska coraz gorzej znosiła więzienie, nie miała żadnej nadziei na pomyślny obrót sprawy, przestała spodziewać się uwolnienia, odczuwała nasilenie myśli samobójczych. W jednym z listów pisała do Jadwigi:

Bo czy Ty wiesz o tem, że Ty jedna tylko stoisz mi na drodze do upragnionego raz spokoju! Jeżeli zrozumiałaś mnie, to błagam Cię, nie gniewaj się - jest to tylko myśl, ale nie zamiar wszak przywiązanie moje do Ciebie od tego mnie wstrzymuje. [Waligórska 2018: 103]

Życie w więzieniu zaczęło się wydawać Waligórskiej odrealnione i nierzeczywiste. Osadzona na nic nie liczyła, niczego nie oczekiwała, nie robiła sobie płonnych nadziei na rychłe uwolnienie. Z coraz większym trudem znosiła kolejne dni, jeden podobny do drugiego, pozbawiona jakiegokolwiek kontaktu ze światem. Pobyt w Cytadeli zaczął przypominać senny koszmar, z którego gorąco pragnęła się obudzić. Pisała:

Więc moja droga Jadziu, obecne życie moje jest snem, mniejsza o przebudzenie! Czyż moje zarówno jak i Twoje życie nie było jednym pasmem takich snów i przebudzeń? Jak śpiemy to marzymy, a jak nas budzą to patrzymy śmiało w rzeczywistość, jakaby ona nie była. [Waligórska 2018: 117]

Z desperackim, czarnym humorem szukała sposobu odebrania sobie życia: „Więc powiadam zostaje mi tylko... «rzucić się w fale srebrzystej Wisły?» spytasz, brrr! za zimno - zostaje mi tylko... 
«przez okno wyskoczyć?» kiedy kraty! «zarżnąć się?» kiedy noża niema!" [Waligórska 2018: 135]. Otruła się 31 grudnia 1886 roku, spędziwszy w więzieniu blisko pół roku.

Listy, które Waligórska pozostawiła, ukazały się w nowatorskiej formie graficznej, a ich edycja stanowi przełom w opracowaniu redakcyjnym archiwalnych dokumentów. W druku pieczołowicie zachowano wszystkie poprawki i skreślenia rękopisu. Niektóre wyrazy przekreślono, inne dopisano nad nimi mniejszym stopniem pisma, pozostawiono ślad korekty, jakiej w rękopisie dokonała autorka. Niektóre frazy, czasem całe akapity, w rękopisie zamazane przez cenzurę, $\mathrm{w}$ druku przybrały postać zaczernionych wersów. Decyzja o zachowaniu wszystkich skreśleń, poprawek, specyficznej ortografii i interpunkcji Waligórskiej - kontrowersyjna z punktu widzenia sztuki edytorskiej - pozwoliła ocalić autentyczny charakter dokumentów. Obcowanie z tekstem opracowanym redakcyjnie tak, aby w jak największym stopniu została zachowana maniera pisarska autorki, pozwala lepiej poznać Bronisławę, którą charakteryzuje nie tylko styl wypowiedzi, lecz także sam sposób zapisu.

Waligórska pisała starannie, nanosiła poprawki, dbała o składnię, ortografię, precyzję wypowiedzi. Starała się używać poprawnej polszczyzny, choć - po latach dzieciństwa spędzonych w Oslo i edukacji u sióstr prezentek w Krakowie - w wypowiedziach pisemnych pewniej chyba posługiwała się językiem francuskim. W jednym z listów zamieściła dopisek: „Przepraszam za francuskie wyrażenia, które się w liście znajdą, ale nie zawsze mogę znaleźć właściwego polskiego słowa” [Waligórska 2018: 105]. Chaotyczna interpunkcja, ortografia nie zawsze zgodna z ówczesną normą, liczne dopiski i skreślenia - to wszystko składa się na specyficzny styl Waligórskiej i umożliwia czytelnikowi stworzenie pełniejszego obrazu jej osoby.

Poruszający jest szacunek, z jakim Rudaś-Grodzka podeszła do listów Waligórskiej i do osoby ich autorki. Badaczka pochyliła się nad korespondencją sióstr z pasją i wrażliwością archiwistki, która nie tylko analizuje treść zachowanych dokumentów, lecz także ma świadomość, że są one świadectwem życia konkretnego człowieka - noszą na sobie jego dotyk, może łzy, towarzyszyły mu 
w trudnych momentach i chwilach uniesień. Dzięki szczególnej postawie badaczki Waligórska, stawszy się bohaterką książki, nie przestała być jej autorką. Mówi własnym głosem, w listach do siostry opowiada własną historię, spisaną zapałką na skrawkach marnego papieru, z chaotyczną interpunkcją i wątpliwą czasami ortografią.

Przełom materialny w humanistyce ma szczególne znaczenie dla badań archiwalnych. Nie tylko kieruje uwagę badaczy ku odnalezionym tekstom, ale także każe dostrzec ich materialną postać. Przyglądamy się rodzajom papieru, analizujemy sposoby jego zaginania i przechowywania, wpatrujemy się w plamy i rozdarcia - ślady historii dokumentu, okoliczności, w jakich powstał i był przechowywany. Rudaś-Grodzka otworzyła nową perspektywę badawczą; przypomniała, że listy (a więc przedmioty, którym się przygląda) pozostawały w materialnym kontakcie z ich autorką bohaterką naukowych dociekań. Zachowana korespondencja to nie tylko świadectwo myśli i refleksji Waligórskiej - to także kartki przez nią wielokrotnie dotykane, z trudem zdobyty papier, na którym prymitywnymi narzędziami stawiała kolejne litery, dłonią skostniałą z zimna lub w gorącym zaduchu źle wietrzonych pomieszczeń, głodna, chora, z obrzydzeniem spoglądająca na ściany celi. Badania archiwalne Rudaś-Grodzkiej to świadectwo kontaktu z drugim człowiekiem, możliwego dzięki zachowanej korespondencji i zdobytej - czasem drogą działalności śledczejwiedzy faktograficznej. Badaczka tak pisze o kontrowersyjnej pozycji „biografistki”:

Już sam termin zdaje się nadużyciem i uzurpacją, więc lepiej zostać przy określeniu: badaczka listów Bronisławy Waligórskiej. Odsłonięcie zajmowanej przez nią pozycji naukowej i sytuacji osobistej ma swoje złe i dobre strony, gdyż demaskuje pozorny obiektywizm badawczy; ta zakładana transparentność powinna posłużyć czytelnikom, którzy zyskują świadomość, że nad listami pracowała kobieta w średnim wieku, feministka, wegetarianka, posiadająca dwa koty, psa i syna. Prywatne odsłonięcie niesie też ryzyko pewnej pretensjonalności, egzaltacji i narcytycznej bufonady, ale w rzeczywistości 
jest swoistą grą, gdyż taka autoprezentacja zawsze ma charakter arbitralny i wybiórczy. Z drugiej strony, co wydaje się zasadnicze, relacja edytorki i autorki listów staje się bardziej ludzka, a więc ułomna, niedoskonała i przez to fascynująca. [Waligórska 2018: 16-17]

Myślę, że Rudaś-Grodzka wypracowała nowy model prowadzenia badań archiwalnych, który „wymaga gestu przeproszenia umarłych za zakłócanie im spokoju” [Waligórska 2018: 17], charakteryzuje się odrzuceniem linearnego postrzegania czasu, przerzuceniem pomostu między dawnym a współczesnym; umożliwia wytworzenie poczucia bliskości z odległą w czasie osobą, reprezentowaną również $w$ aspekcie materialnym, jak gdyby cielesnym, przez zachowane dokumenty. Konsekwencją tak pojętego przełomu materialnego będzie więc swoiste ujawnienie badaczy i badaczek, którzy w kontakcie z drugim, wychylającym się z przeszłości, człowiekiem muszą odsłonić swoją - nie tylko naukową - tożsamość. Gest rezygnacji z transparentności obejmuje obie strony ponadczasowego dialogu i sprawia, że edytowany tekst nie tylko jest sposobem przywracania pamięci, ale także ma szansę wybrzmieć w teraźniejszości, przemówić głosem postaci minionych, sprawić, że czytelnicy przez moment będą mogli doświadczyć autentycznego kontaktu z autorką. Listy z Cytadeli 1886 są więc świadectwem relacji badaczki i autorki oraz szansą dla czytelników na bliskie spotkanie z Bronisławą Waligórską patriotką, socjalistką, siostrą, nauczycielką, tłumaczką, kobietą dzielną, nieszczęśliwą i samotną.

\section{Bibliografia}

Waligórska Bronisława (2018), Listy z Cytadeli 1886, listy przygotowała do druku, opatrzyła komentarzami i wstępem biograficzno-interpretacyjnym Monika Rudaś-Grodzka, Wydawnictwo IBL PAN, Warszawa. 
Agnieszka Kwiatkowska

\section{How to research personal texts - a close meeting with Bronisława Waligórska}

The author of 19th-century letters, Bronisława Waligórska - a socialist activist - was arrested and imprisoned in the Warsaw Citadel in July 1886. She sent letters from prison to her sister Jadwiga, who visited her in an attempt to satisfy the prisoner's most pressing needs. The surviving correspondence is a testimony of the living conditions of the Citadel's prisoners and the internal life of Bronisława, who was gradually losing her spirit and the will to fight. On December 31, 1886, she swallowed sulphur from matches and died a few days later. Waligórska's letters are a testimony of the time spent in prison, but not only. In the letters to her sister, she discussed such topics as the conditions of everyday existence, life in prison and organisation, but also included her reflections on culture, literature and art. She tried to fill her time in prison with translation work. The surviving letters have been published in an innovative graphic form and their edition is a breakthrough in editorial work on archival documents. The print meticulously keeps all the corrections and crosses of the original. Monika Rudaś-Grodzka treated Bronisława Waligórska’s letters with great respect; she approached them with a passion and sensitivity of an archivist who not only analyses the content of the remaining documents, but is always aware that they are a testimony of the life of a particular person. Thanks to the peculiar attitude of the researcher, Waligórska, while being the protagonist of the book, never stopped being its author. The edition of letters from prison are accompanied by an editor's note, a description of the terms of publications, a timeline, the main protagonist's prison biography and a selection of documents concerning the investigation.

Keywords: letters; personal literature; women's writing; inconspicuous work; document's material value.

Agnieszka Kwiatkowska - profesorka w Zakładzie Literatury xx wieku, Teorii Literatury i Sztuki Przekładu UAM, badaczka literatury xx wieku, autorka monografii poświęconej twórczości Juliana Przybosia Tradycja, rzecz osobista. Julian Przyboś wobec dziedzictwa poezji (2011) oraz redaktorka edycji Pism rozproszonych tego twórcy (2018). Obecnie zajmuje się pisarstwem kobiet, zwłaszcza poezją dla dzieci pisaną przez kobiety. 
Odkrycia 
